\title{
Familia-aniztasunaren trataera Haur Hezkuntzako gelan: prestatuta al daude irakasleak?
}

\author{
Attention to family diversity in the preschool classroom: \\ Are teachers ready? \\ Haizea Ramos Tejada, Nuria Galende Pérez* \\ Bilboko Hezkuntza Fakultatea, Leioa
}

LABURPENA: Familiaren bilakaerak kontzeptualizazio berria ekarri du, hainbat familia-eredurekin batera. Hori dela eta, ikerketa honek familia-aniztasuna ezagutzea eta Haur Hezkuntzako etapatik ematen zaion erantzuna aztertzea du helburu. Horretarako, ikerketa bat egin da Bilboko 7 eskolatako 48 irakaslerekin. Ad hoc galdetegi bat sortu da, ikastetxe horiek familia-aniztasunari ematen dioten erantzuna aztertzeko, bai profesionalen ikuspuntutik, bai erakundetik bertatik. Jasotako datuak kuantitatiboki aztertu ostean, bi mailetan hobetzeko alderdiak daudela ondorioztatu da, baita zenbait aldagaik, hala nola profesionalen adinak edo ikastetxeetan dauden familia-ereduek eragina dutela eskolan familia-aniztasunari ematen zaion tratamenduan. Azkenik, guztiak hezkuntzan dituen inplikazioak eztabaidatzen dira.

GAKO-HITZAK: familia-aniztasuna, Haur Hezkuntza, irakasleria, jarrerak, eskola inklusiboa.

ABSTRACT: The evolution of the family has given rise to a new conceptualisation, along with different family models. Thus, the aim of this research is to be aware of family diversity and analyse the response given by the school at Early Childhood Education. To that end, a study with 48 teachers from 7 schools of Bilbao has been carried out. An ad hoc questionnaire has been developed, in order to evaluate the response given to family diversity by those schools from the point of view of the professionals as well as from the institution itself. Once the gathered information has been examined, it comes to the conclusion that there are aspects to improve in both levels and that variables, such as the age of the professionals or the family models with which they work at school, have influence in the treatment given to family diversity in those schools. Finally, the educational implications of the entire above are discussed.

KEYWORDS: family diversity, Early Childhood Education, teaching staff, attitudes, inclusive school.

\footnotetext{
* Harremanetan jartzeko / Corresponding author: Nuria Galende Pérez. Euskal Herriko Unibertsitatea. Garapenaren eta Hezkuntzaren Psikologia Saila. Sarriena z/g. 48940 Leioa. - nuria.galende@ehu.eus - https://orcid.org/0000-0002-2195-6912

Nola aipatu / How to cite: Ramos Tejada, Haizea; Galende Pérez, Nuria. (2020). «Familia-aniztasunaren trataera Haur Hezkuntzako gelan: prestatuta al daude irakasleak?» Tantak, 32(2), 127-159. (https://doi.org/10.1387/tantak.21703).

Jasotze-data: 2020/05/06; Onartze-data: 2020/10/26.

ISSN 0214-9753 - elSSN 2444-3581 / (c) 2020 UPV/EHU
}

(c) $\oplus_{\mathrm{By}}$ Obra hau Creative Commons Atribución 4.0 Internacional-en 


\section{MARKO TEORIKO ETA KONTZEPTUALA}

\subsection{Familiaren bilakaera}

Familiaren kontzeptua historian zehar aldatuz joan da eta gaur egun hura definitzeko hitz egokiena aniztasuna da (Mujika, 2005). Taberner-ek (2012) adierazten duenez, Xx. mendearen erdialdean, Europan onartutako familia-eredua ezkondutako bikote heterosexual batek eta haien seme-alabek osatzen zuten. Hots, gizon eta emakume bat ezkontzen ziren eta, ondoren, seme-alaba biologikoak izaten zituzten. Gainera, ezarritako eredu horretatik urruntzeak ondorio negatiboak zituen; bai legeak zigorra ezar zezakeelako, bai familia horiek gutxiespen soziala jasotzeko arriskua zeukatelako. Beraz, orain dela gutxi arte familiek eredu berari jarraitu izan diote. Halaber, amak etxeko lanen zein zainketa-lanen ardura zuen bitartean, aitak produkzio-lanak garatzen zituen familiarentzako mantenua lortzeko. Ez hori bakarrik, aitak autoritatea zeukan eta familiaren ordezkari zen (González, 2009).

Azken urteetan, aldiz, eredu patriarkal horrek eraldaketak izan ditu, zeren eta «Espainiar estatuan gertatutako aldaketa sozialek eragina izan baitute gaur egungo familiaren ezaugarrietan eta bilakaeran» (Aguado, 2010, 128. or.). 1975etik aurrera gertatutako aldaketak ugariak izan dira eta familia espainiarren irudi soziala aldatu dute. Aldaketa nagusien artean honako hauek nabarmendu ditzakegu.

Alde batetik, legegintza-aldaketek eragina izan dute familien testuinguruan, eta familiaren alde juridikoa pixkanaka aldatu egin dute. 1978ko Konstituzioak dibortzioa arautzeko bidea ireki zuen eta 1981eko dibortzio-legeak ezkontzaren arauketa aldarazi zuen (Iglesias de Ussel, 2001). Legeak ezkontza desegitea baimendu zuen, alegia, dibortzioa onartu zen. Ondorioz, familia berreraikiak eta banatutako gurasoen familiak sortzen hasi ziren.

80ko hamarkadaren amaieran ere aldaketa nabarmenak izan ziren, ugalketa lagunduari eta adopzioei buruzko legegintzek bikoterik izan gabe seme-alabak izateko aukera eman baitzuten (López, Díez, Morgado eta González, 2008). Hau da, guraso bakarreko familiak, ugalketa lagunduaren bidez jaiotako haurren familiak eta adopziozko familiak sortu ziren.

Geroago, 2005. urtean, Kode Zibilean jasotako aldaketek homosexualen bikoteak legitimatu zituzten (González, 2009). Hori dela eta, bikote homosexualek ezkontzeko zein adoptatzeko eskubidea lortu zuten. Hortaz, familia homoparentalei legezkotasuna eman zitzaien.

Beste alde batetik, familiak osatzeko modua aldatuz joan da, familien eraketak jadanik ez duelako zertan ezkontzarekin hasi. 1975etik hona, ezkontza kopuruak beherakada izan duenez, elkarrekin ezkondu gabe bizi diren bikoteen kopuruak gora egin du. Era berean, ezkontzeko adina igo egin 
da eta ezkongabeak nahiz izatezko bikoteak ugaritu egin dira (Iglesias de Ussel, 2001).

Jaiotza-tasak ere jaitsiera izan du eta familiak txikiagoak dira. Espainian gero eta familia kopuru gehiago izan arren, familien batez besteko kideen kopuruak behera egin du. Hau da, 2013. urtean Espainian 18.217.300 etxe zeuden (INE, 2014), eta 2019. urtean, 18.625.700 (INE, 2020). Horrez gain, 2019ko jaiotza kopuru totalaren aldakuntza 2018 urtekoarekin konparatuz negatiboa izan da $(-3,49)$ (INE, 2019).

Horrez gain, rol aldaketak izan dira. Esate baterako, emakumeen lana etxetik kanpora zabaltzea familiaren ikuspegi berrian eragin handia izan duen gertakari sozial bat izan da (Kallinsky, 2010). Ondorioz, etxeko lanak eta seme-alaben ardura banatzen hasi dira, nahiz eta oraindik orekatuak ez izan. Egia da berdintasunaren aldeko ikuspegiak eta jarrerak daudela, legeak dagoeneko ez baitio gizonari nagusitasuna ematen. Horregatik, gizonek eta emakumeek eskubide eta betebehar berberak dituzte eta autoritatea familian dauden helduen artean partekatu ohi da (González, 2009). Praktikan, ordea, emakumea produkzio-lanetan hasi arren, etxeko lanen banaketak desorekatua izaten jarraitzen du.

Nolanahi ere, familiaren bilakaerak familiaren kontzeptualizazio berria ekarri du, kontzeptu zabal eta aldakor gisa definituz. Dagoeneko familiak ez du zertan ezkondutako guraso heterosexualez eta haien seme-alaba biologikoez osatuta egon. Familia-eredu hori urte askoan eredu tradizionala izan da, baina familiaren ezaugarriak aldatuz joan dira eta gaur egun «familiaren izaera konplexua, anitza eta dinamikoa» (Aguado, 2010, 130. or.) dela esan dezakegu:

Ezkontza ez da lotura bakarra, bereizketak eta beste familia bat eratzea askotan gertatzen dira, bi guraso edo guraso bakarreko familiak osatzen dira, eta seme-alaben kopurua jaisteaz gain, bide ezberdinetatik etor daitezke: adopzioa, laguntza bidezko ugalketa, lehenagoko harremanak, eta abar. Bestalde, gaur egungo familiaren definizioan etxe berean bizi ez direnek familia osa dezakete, familia osatzeko prozesuan dibortzioak, bigarren ezkontzak egon daitezke, eta familia homoparentalak gero eta presentzia handiagoa izaten ari dira. (Aguado, 2010, 131 or.)

Hortaz, familiaren kontzeptua askotarikoa da, familia-eredu desberdinak daudelako; eta dinamikoa, familiako kideak, rolak, harremanak eta familiak eratzeko moduak aldatuz doazelako. Hau dela bide, familia errealitate sozial aldakorra da (Garrido, 1995; Miret, 2016), historian zehar aldaketak sufritu dituena eta haietara egokitu dena.

Edonola ere, nahiz eta definizio desberdinak egon, beharrezkoa da familia ulertzeko honako elementu hauek kontuan hartzea: kideak, harremanak eta funtzioak (López-Larrosa eta Escudero, 2003). Hots, familiaren definizioak familia osatzen duten kideak (ama, aita, seme-alabak, aitona-amonak...), haien 
arteko harremanak (odolkideak, legalak, ...) eta funtzioak (zainketa, eginkizun afektibo eta emozionala, sozializatzeko funtzioa, hezkuntza funtzioa eta abar) barne hartzen ditu. Ondorioz, aipatutako elementuen konbinaketak familia-eredu ezberdinak sortzen ditu, familiaren kontzeptua osatzen dutenak.

\subsection{Familia-eredu ezberdinak}

Historian zehar gertatu diren aldaketen ondorioz, familia-eredu desberdinak agertu direla ikusi da. Beraz, gaur egungo askotariko familia-ereduen oinarrizko ezaugarriak aztertuko dira.

\section{Familia nuklearra}

Gurasoez eta seme-alabez osatutako familia, barnean hartzen ez dituena aitona-amonak edota beste senitarteko batzuk. Hots, familia hedatuaren aurkakotzat ulertzen da. Cambridge Academic Content Dictionary-ren (d.b.) arabera, familia nuklearra bi gurasoek eta haien seme-alabek osatzen duten gizarte-unitatea da.

Europan eta Espainian hau izan da eredu tradizionala urte askoan, gizartean instituzionalizatuta zegoena zelako (Taberner, 2012). Hala ere, aldaketak sufritu ditu, egungo familia nuklearretan gurasoak ez daudelako beti ezkonduta eta seme-alabak bide desberdinetatik iristen direlako (biologikoak, adoptatuak, ...) (Aguado, 2010). Hau da, ikerketa antropologikoak (The Editors of Encyclopedia Britannica, d.b.) ondorioztatu du eredu honek askotariko formak izan ahal dituela: gurasoak ezkonduta edo ezkondu gabe egon daitezke, sexu bereko bikoteek osa dezakete, eta abar.

\section{Familia hedatua}

Familia nuklearraren hedapenari esaten zaio. Familia-eredu hauetan gurasoak eta seme-alabak egoteaz gain, beste ahaide batzuk ere badaude (Navarrete, 2010).

\section{Guraso bakarreko familia}

Guraso batez eta bere seme-alabez osatutako familia da. Cortés eta Cantón autoreek (2010) esaten dutenez, «son aquellas en las que un progenitor convive con y es responsable en solitario de sus hijos menores o dependientes.» (35. or.). Alegia, guraso bakar bat bere seme-alabekin bizi da eta bera bakarrik da haien arduradun. Bestalde, adineko pertsona baten kargu egiten dena ere familia-eredu honen barnean dago (Hik Hasi, 2004). 
Beraz, guraso bakarreko familietan pertsona batek beregain hartzen du familiaren pisua.

Familietan ama baino ez dagoenean, seme-alabek gizonezkoaren eraginaren falta igartzen dutela uste da. Golombok autorearen (2006) arabera, aldiz, aitaren generoa ez da garrantzitsua seme-alaben maskulinitatea eta feminitatea garatzeko orduan; garrantzitsua izatekotan, aitarik ez duten haurren edo inplikazio handiko aita duten haurren maskulinitatea eta feminitatea ezberdina izango litzateke familia nuklearren seme-alabenarekin konparatuz, baina ez dago horren ebidentziarik.

\section{Adopziozko familia}

Adopziozko familietan gurasoak ez daude genetikoki erlazionatuta seme-alabekin (Golombok, 2006). Hots, ez dago harreman biologikorik ahaideen artean. Gainera, familia-eredu horrek errealitate desberdinak hartzen ditu barnean; hala nola, familia nuklearrak, homoparentalak, monoparentalak, adoptatu baino lehen seme-alaba biologikoak zituzten familiak edo behar bereziak dituzten haurrak adoptatzen dituzten familiak, besteak beste.

\section{Familia homoparentala}

Sexu bereko bikoteez osatutako familiak dira; hau da, homosexualak diren bi aitaz edo bi amaz osatutakoak (Mujika, 2005). Familia horietan ere aniztasuna nabarmena da, «nuklearrak, gurasobakarrekoak, berreraikiak edota zabalak» (Aguado, 2010, 136. or.) izan daitezkeelako.

\section{Familia berreraikia}

Familia berreraikia bikotekide bat, gutxienez, beste bikote batetik datorrenean eratzen da. Horrez gain, mota desberdinak daude; esate baterako, izan daiteke bikotekideek aurreko beste harremanen batean seme-alabaren bat izatea edo seme-alabarik ez izatea. Kasu honetan ere, askotariko errealitateak daude:

Daitekeena da bikote berriko kide batek zein biek lehenagoko bikotekidearekin izandako seme-alabaren bat edo gehiago izatea, berekin bizi direnak edo ez direnak; edo, ez batak ez besteak ez izatea seme-alabarik; baita bikote berriko kideek bien artean izandakorik izatea edo ez izatea ere. (González eta Triana, 2001, 374. or.)

Oliva, Parra eta Antolínek (2010) esaten dute, ordea, familia berreraikia izateko seme-alabaren bat aldez aurretiko harreman batetik etorri behar dela. 


\section{Harrera-familia}

Familia hauetan, arrazoi ezberdinengatik beren guraso biologikoekin bizi ezin diren haurrak daude. Beraz, harrera-familiek haurrak zaintzen dituzte aldi baterako. Modu honetan, haurra beste pertsona batzuekin bizi da bere testuinguru familiarrean dauden arazoak konpontzen diren bitartean.

Harrera-familietan dauden haurrek familia biologikoarekin harreman juridikoa eta afektiboa mantentzen dute; familia-eredu hauen funtzioa babesa eta sostengua ematea delako, egoerak eta baldintzak ahalbidetzen dutenean haurra bere familia biologikoan berriro integratzeko (Aldeas Infantiles SOS, 2018).

\section{Etorkinen familia}

Bere herrialdetik atera eta beste batera bizitzera joan diren familiak. Etorkinen kultura eta ohiturak ezberdinak izan daitezke harrerako kulturarekin konparatuz. Gainera, familia hauen historia mugikortasun prozesu batek markatuta dago, errealitate berrietara azkar egokitzea eskatzen duena. Ondorioz, errealitate berrietara moldatu behar dira, berregituraketak eginez. Etorkinen familiek eraldaketa sakonak eta krisialdiak jasaten dituzte, banaketa zein itxaropen eta planen doitzea dakartena (Terrén, 2007).

\section{Banatutako gurasoen familia}

Gurasoak banatuta daude eta ez dira elkarrekin bizi, baina seme-alabekiko ardurak betetzen jarraitzen dute. Banantzeak edo dibortziatzeak oreka-galtzea eragin dezake eta trantsizioak eta berrantolaketak sortzen ditu (Pedro-Carroll, 2005). Hori dela eta, komenigarria da eskolan neurriak hartzea (López-Larrosa, 2009); adibidez, banatutako bi gurasoei ikaslearen berri emanez.

\section{Ugalketa lagunduaren bidez jaiotako haurren familia}

Ugalketa lagunduaren bidez familiaren ugaltze-funtzioa familiatik kanpo burutu daiteke eta guraso eta seme-alaben arteko harreman genetikoa ez da ezinbestekoa. Bestalde, ugalketa lagundua familia-eredu desberdinetan egon daiteke; adibidez, familia nuklearretan, homoparentaletan, monoparentaletan edo familia berreraikietan (Arranz, Olabarrieta, Galende, Manzano eta Martín, 2010).

\section{Subrogazioaren bidez sortutako familia}

Subrogazioa gertatzen da emakume bat beste pertsona batentzat haur batez erditzen denean. Bi motatakoa izan daiteke (Golombok, 2006): subro- 
gazio partziala esaten zaio eskaera egiten duen aitaren hazia eta ordezko amaren obulua erabiltzen direnean; subrogazio osoan, berriz, obulua eta hazia eskaera egiten duten gurasoenak dira. Horrez gain, nahiz eta ohikoa ez izan, emaileek emandako haziak eta obuluak erabiliz ere subrogazioa gerta daiteke.

Espainian, subrogazioaren bidez sortutako haurdunaldia ez da legezkoa (Ley 14/2006). Horregatik, teknika honen bidez sortutako familiek legezkoa den beste herrialde batean aurrera eramaten dute prozedura, hala nola Estatu Batuetan.

Hala ere, familia-ereduen sailkapen bat aurkeztu arren, familia-ereduak mugagabeak dira, elkarketak modu ezberdinen bidez gerta daitezkeelako. Ondorioz, familia nuklear bat adopziozko familia ere izan daiteke aldi berean, edota ugalketa lagunduaren bidez jaiotako haurren familia guraso bakar batez osatua egon daiteke. Hori dela eta, familia batzuk familia-eredu desberdinen barneen sailka daitezke, familia-ereduen eraketa-prozesua homogeneoa ez delako (Oliva et al., 2010).

Are gehiago, Golombok-ek (2006) dio garrantzitsuena ez dela familien eraketa edo familia-eredua, baizik familien barnean gertatzen dena. Alegia, haurren garapen psikologikoan eragina daukana familiaren bizi-kalitatea da. Hortaz, familia-eredu batzuk ez dira beste batzuk baino hobeak. Hori horrela delarik, familiak haurren garapenean duen eragina ezagutzea garrantzitsua da, familia-eredua edozein izanda ere.

\subsection{Familiaren eta eskolaren eragina haurraren hezkuntza-prozesuan}

Familia babesa eta laguntza ematen digun giza taldea da, haurtzaroan batez ere. Haurrak eta helduak elkartzeko funtsezko espazioa da. Espazio horretan, maitasun-harremanak gertatzen dira, balioak transmititzen dira, nortasuna eratzen da, garapena sustatzen da, ezagutza eratzen eta transmititzen da eta gizarteratzeko beharrezkoak diren gaitasunak garatzen dira. Hau da, familia lehen sozializazioaz arduratzen da (Kallinsky, 2010). Bizitzako lehenengo urteetan gizarteratze-agente garrantzitsuena da, eskolarekin batera.

Olivak eta Palaciosek (2001) esaten dutenez, «haurrak gizarteratzeko prozesuan familia ardatz nagusia izan arren, eskolak ere ezinbesteko rola betetzen du prozesu horretan» (321. or.). Biek haurrak zaintzeko eta arriskuetatik babesteko funtzioa betetzeaz gain, haurren hezkuntza eta garapena sustatzen dute.

Bronfenbrennerren (2001) eredu ekologikoaren arabera, mikrosistematik zenbat eta gertuago egon, eragina orduan eta zuzenagoa izango da. Ondorioz, eskolak eta familiak interakzio zuzenak dituztenez haurraren egunerokotasunean, haien arteko interakzioek haurraren garapenean eragin handia izango dute. 
Hori dela eta, biak hezkuntza-prozesuan ezinbestekoak direnez, beharrezkoa da elkarren arteko lankidetza, zeren eta familiaren eta eskolaren arteko harremanak ikaskuntza baldintzatzen baitu (López-Larrosa, 2016).

\subsection{Eskola askotariko familia-ereduen aurrean}

Eskola zein familia haurren hezkuntza-prozesuan ezinbestekoak direnez, eskolak familia guztien errealitatea kontuan hartu behar du. Baina familiaren bilakaera dela eta, familia-aniztasunak hezkuntza-sistemari erronka bat ekarri dio (Grau eta Fernández, 2015) eta eskolari zaila gerta dakioke gaia lantzea, konplexua (Aguado, 2010) eta oso heterogeneoa (Triana, Ceballos eta Rodríguez, 2019) baita; baina etengabeko aldaketek agerian jartzen dute hezkuntza berriztatzeko ildoak sustatzeko beharra eta, horien artean, familiaren eta eskolaren arteko harremana indartzeko beharra aurkitzen da (Rodríguez-Ruiz, Martínez-González eta Rodrigo, 2016).

Gorago esan bezala, arlo juridikoan eta gizarte-mailan familia-aniztasuna bere lekua lortuz doa, baina badirudi oraindik ez dela lortu errealitate honen normalizazioa, eta eskolan ere azkeneko hau gertatzen da askotan (Abril eta Peinado, 2018). Horregatik, egungo eskolaren lan bat da gizartean dagoen aniztasun hori geletan normaltasunez islatzea; horretarako, irakasleek familia-errealitatea ezagutu beharko lukete, eta eskola-aniztasunaren ispilu eta leiho bihurtu (Koerner eta Hulsebosch, 1996). Ispilua, haur guztiek beren esperientziak islatuta ikusteko, eta leihoa, besteen bizitza eta ideietara irekita egoteko. Ez hori bakarrik, eskolak haurren errealitateak islatzeaz gain, beste pertsona batzuen errealitatea ere erakutsi behar du; haurrek aniztasunarekiko tolerantzia, errespetua eta estimua garatzeko (González, 2009).

Askotariko familia-ereduak kontuan ez hartzeak hezkuntza-desparekotasuna sortzen du. Hortaz, haur guztientzat aukera-berdintasuna, ekitatea, ongizatea eta eskolako giro positiboa lortzeko, familia-aniztasuna ezagutzea eta kontuan hartzea garrantzitsua da (Collet eta Tort, 2017).

Horrela jasotzen da LOMCE legean (Ley Orgánica 8/2013), familiak elkarlanean aritu behar direla eskolarekin eta eguneroko lanarekin konpromisoa hartu behar dutela dioenean. Hori horrela izan dadin, familiak onartuak sentitu behar dira eta eskolarekin identifikatuak; hots, ez lirateke baztertuta sentitu behar.

Ildo beretik, HEZIBERRI 2020k (Eusko Jaurlaritza, 2014) ere azpimarratzen du «etxekoekin elkarlanean jardutea eta, beraz, eskola-ingurunea eta familia-ingurunea elkarrengandik ahalik eta hurbilen egon daitezen saiatzea metodo bikaina da» (44. or.), edo «pertsona guztiek ikasteko aukera izan dezatela babesteko, aintzat hartu behar da ikasleen arteko aniztasuna, eta aberastasun modura ulertu» (47. or.). 
Baina, ba al dago gure eskola prest aipatzen ari den honi guztiari erantzun apropos bat emateko? Ez bakarrik eskola instituzio gisa, baizik eta eskolan lan egiten duten profesionalak ere.

Esate baterako, familiaren arloan existitzen den aniztasun hau kontuan hartuta, egile batzuek eskolako materialen azterketaren beharra aldarrikatzen dute (López et al., 2008), eta, dirudienez, familia nuklearrak erreferentziazko eredua izaten jarraitzen du eskola gehienetan eta haietan erabiltzen diren materialetan. Beraz, ezinbestekoa da askotariko errealitateak kontuan hartzea eta sentsibilitate handiagoz aritzea (Hik Hasi, 2004).

Aldatu beharreko alderdien artean, jaiotzari buruzko fitxa edo zuhaitz genealogikoen osaketak aipa ditzakegu, familia guztiek ezin dituztelako erantzun. Era berean, jarduera batzuk birpasatu eta moldatu beharko lirateke - hala nola, aitaren edo amaren eguna - , zenbait praktikak familia batzuk irudikatzen ez dituztelako (González, 2009). Halaber, eskolan familia-eredu desberdinak agerikoak izatea funtsezkoa da, bai haurraren heziketarako bai eskolarentzat; adibidez, homosexualak diren haurrak erreferente bat izateko, isolatuta ez sentitzeko (Hik Hasi, 2004).

Beraz, beharrezkoa da errealitatean dauden familia-eredu desberdinak naturaltasunez tratatzea, eskolan gai batean bereziki landu barik. Haurrak beren familia-ereduan onartuak sentitu behar dira, eta besteak errespetatzen ikasi behar dute. Horretarako, protokoloak eta lanerako gidak lagungarriak dira, familiaren gaia ikuspuntu zabal batetik lantzeko aukera ematen dutelako (Aguado, 2010). Gainera, askotariko materialak behar dira, ikasleek aniztasunaren errealitatea ikusteko.

Zentzu honetan, eskolak familia-eredu guztiak errespetatuak eta onartuak sentitzeko espazioa izan behar du (González, 2009). Horretarako, eskolan irudikatzen den familiarekin identifikatuta sentitzeko aukera izan behar dute. Izan ere, egile batzuek diotenez, Haur Hezkuntzako materialetan transmititutako familiaren irudia nuklearra da batez ere, beste ereduetako erreferentziarik gabe (López et al., 2008; Richard, 2005), nahiz eta gaur egun familia-aniztasuna islatzen duten hezkuntza-baliabide zein material ezberdinak eskuragarri egon (López et al., 2008). Adibidez, familia ezberdinak islatzen dituzten liburuak (Familium XX1, Nuestra Casa, Familia guztien aldeko ipuinak, Txinatik etorritako printzesa, Paula tiene dos mamás, Teo lagun baten etxean), filmak (Buscando a Dory) edota proiektuak (Familia Milakolore), besteak beste.

Aurreko guztia zentroei dagokienez; baina zer esan daiteke zentroetan lan egiten duten profesionalei buruz? Haiek ere badute eragin handia gai honen lanketan.

Ikerketa ezberdinek erakutsi dute, esate baterako, irakasleek itxaropen desberdinak dituztela egitura familiarraren arabera. Akademikoki, emaitza txarragoak espero dira familia ez-konbentzionaletan bizi diren ikasleengandik (Abril eta Peinado, 2018). Beraz, familia-aniztasunari buruz ira- 
kasleek dituzten aurreiritziek haien irakasteko moduan eragina izango dute eta, era berean, ume hauek eskolan dituzten emaitza zein bizipenetan. Gurasoek ere, noski, nabaritzen dute hau. Ikerketa batean aurkitu zuten guraso askoren ustez haien eskolak familia-eredu guztiekin inklusiboak zirela, zorionez; baina, modu berean, beste batzuen bizipena zen eskolak toleranteak baina ez-inklusiboak zirela; eta, beste batzuk marginatuak sentitzen ziren eskola horietan, bereziki ama lesbianak (Goldberg, Black, Sweeney eta Moyer, 2017). Ondoriozta daitekeena da gauzak aldatuz doazela, baina asko dagoela oraindik egiteke.

Ildo beretik, formakuntzak ere eragina dauka. Familia-aniztasunari buruzko formakuntza oso eskasa da (Abril eta Peinado, 2018). Formakuntza ezinbestekoa da irakasleriaren artean existitzen diren familia-eredu batzuekiko ezjakintasuna eta aurreiritziak gainditzeko (Morgado, Jiménez eta González, 2009). Horrela diote batzuetan profesionalek, berentzako formakuntza gehiago eskatzen dutenean (Triana eta Rodrigo, 2010). Gaiari buruzko ezagutzak handituz joatea ezinbestekoa izango da irakasleen aurreiritziak ezabatzeko; izan ere, gero eta kontzientzia handiagoa bada ere, oraindik aurreiritziek, zoritxarrez, badute beren lekua.

Adibidez, Haur Hezkuntzako profesionalak izateko ikasten ari ziren ikasleekin egindako ikerketa batean, emaitzek erakutsi zuten irakasleak familia-aniztasunaren alde daudela, bai eta familia-eredu batzuei buruzko ikuspuntu baztertzaileak agertzen zirela ere (Abril eta Peinado, 2018). Beste batean, ordea, aurkitu zen irakasleak izateko ikasten ari direnek jarrera moderatuak dituztela, aurreiritzi gutxiagorekin aurreko belaunaldietako jendearekin konparatzen baditugu (Triana et al., 2019).

Horren arrazoia, egile hauen esanetan, honako hau izan daiteke: «Haber nacido a las puertas del siglo XXI ayuda a la hora de ver de forma más natural la diversidad» (Triana et al., 2019, 72. or.). Adibide moduan homoparentalitatea aipatzen dute, eta belaunaldi berrien jarrera positiboago horren arrazoiak bilatzen dituzte: kasu errealak ezagutzea, zeinetan familia-adaptazioa ona den; ezkontza hauen legalizazioa; edota bisibilizazio handiagoa existitzea gaur egun, esate baterako, bikote ospetsuen bitartez. Edonola ere, badirudi irakasleen adinaren arabera jarrera desberdinak aurkitu daitezkeela gai honen inguruan.

Hau dela bide, lan honen helburu nagusiak familia-ereduen aniztasunaren presentzia eskolan ezagutzea eta eskolatik familia-aniztasunari ematen zaion erantzuna aztertzea dira. Helburu nagusi hori gehiago zehaztuz, lanaren helburu zehatzak, eta dagozkien hipotesiak, honako hauek dira:

1. Haur Hezkuntzako geletan dauden familia-ereduak ezagutzea. Hipotesia da familia-eredu ezberdinak aurkituko direla, nagusia nuklearra bada ere. 
2. Gela horietako profesionalen prestasuna ezagutzea (formakuntza, haien iritzi edo ezagutza desegokiak, gelan egiten duten lanketa, materialen ezagutza...). Zentzu honetan, espero da profesionalak prest ez egotea familia-aniztasunari modu egoki batean erantzuteko.

3. Ikertutako zentroak prest al dauden ezagutzea. Kasu honetan ere, zentroak prest ez egotea da espero dena.

4. Profesionalen kasuan, adinaren arabera jarrera desberdinak aurkitzen al diren ezagutzea. Espero da aurkitzea gazteenek jarrera irekiagoa izatea.

5. Profesional hauen geletan edota zentroetan aurkitzen den familiaereduen kopurua aurreko guztiarekin lotuta dagoen ikertzea. Espero da aurkitzea aniztasun handiagoa (familia-ereduen kopurua handiagoa) dagoen lekuetan erantzuna egokiagoa edo irekiagoa izatea, bai indibidualki, bai eta zentroan ere.

\section{METODOLOGIA}

\subsection{Parte-hartzaileak}

Lagina Bilboko 7 eskolatako Haur Hezkuntzako 48 irakaslek osatzen dute, eta guztiak emakumeak dira. Adinari dagokionez, laginaren ia erdia 51-60 adin tartean kokatzen da. Jarraian, 41-50 adin tartekoek \% 22.92 osatu dute, eta 31-40 adin tartekoek, \% 16.67. Ehuneko baxuena 21-30 eta 61-70 adin tartekoek dute, \% 10.42 eta \% 2.08 portzentajeekin, hurrenez hurren. Eskolen hautaketari dagokionez, intzidentalki egin da.

\subsection{Tresna}

Datuak biltzeko galdetegi bat erabili da (ikusi 1. eranskina), irakurritako informazioan eta marko teorikoan oinarrituta, ikerketarako espresuki edo ad hoc sortu zena. Galdetegian 5 atal bereiz daitezke. Lehenengo atalean, gelan dauden familia-ereduei buruz galdetzen da. Bigarren atalean, 17 baieztapen agertzen dira, eta parte-hartzaileak adostasun neurria adierazi behar du, 1etik 4rako Likert eskala erabilita: guztiz desados (1), zertxobait desados (2), zertxobait ados (3) eta guztiz ados (4). Baieztapenak neurtu nahi ziren gai desberdinekin lotuta daude: formakuntza, iritzi / ezagutza eta familia-aniztasunaren lanketa gelan. Galdetegian sailkapen hau ez zen ikusgai egon. Hirugarren atala familia-aniztasuna lantzeko ezagutzen dituzten materialei zuzenduta dago. Han, 8 material aipatzen dira, eta beste batzuk idazteko aukera ere eman zaie. Laugarren atalean, 
eskolako material pedagogikoetan (ipuin eta testu literarioetan, filmetan, joko eta jostailuetan, antzerkietan, abestietan eta marrazki eta argazkietan) orokorrean agertzen den familia-eredua adierazteko eskatzen zaie. Eta, azkenik, bosgarren atalean zentroan aurrera eramaten diren ospakizunei, jarduerei eta protokoloei buruz galdetzen zaie, modu dikotomikoan.

Erreminta sortzeko prozeduran, eta desiragarritasun soziala ekidin edo kontrolatzeko helburuarekin, Poó, Ledesma eta Montes-en (2010) lanaren ildoak kontutan hartu dira.

\subsection{Prozedura}

Prozedurari dagokionez, lehenengo pausoa eskolekin harremanetan jartzea izan da, lana aurkezteko eta haien parte-hartzea eskatzeko. Gero, informatutako baimen-dokumentuak prestatu dira (López-Abadía, 2011); haietan, aurkezpena, ikerketaren inguruko informazioa, galdesorta betetzeko prozeduraren xehetasunak eta parte-hartzaileen eskubideak azaltzen dira. Baimen-dokumentu horren sorkuntzan EHUko batzorde etikoak (CEISH) zehaztutako irizpideak kontuan hartu dira, etika profesionala eta datuen babesa bermatzeko asmoz. Baimen-dokumentua galdesortaren hasieran atxikita aurkezten da, hartzaileek hura bete baino lehen testuinguruan kokatzeko eta konfidentzialtasuna bermatuko zela jakiteko. Galdetegi guztiak jaso ondoren, haien bidez lortutako datuak SPSS 23.0 programa estatistikoarekin aztertu dira, ondoren azalduko den bezala.

\subsection{Datu-analisia}

Datu-analisi desberdinak egin dira, aldagaien izaera eta bilatutako helburuaren arabera. Hurrengo atalean hobeki zehaztuko dira pausu bakoitzean aurrera eramandako analisiak, baina, erabilitako guztiak laburbilduz, honelako analisiak egin dira.

Alde batetik, estatistiko-deskribatzaileak (batezbestekoa, desbideratze tipikoa) zein portzentajeak kalkulatu dira hainbat aldagaitan; esate baterako, geletan familia-eredu bakoitzaren presentzia edo irakasleen formakuntza, aurreiritziak zein gelako gai honen lanketa-maila. Bestetik, ANOVA analisiak aurrera eraman dira, ikertutako aldagaietan irakasleen adinaren araberako desberdintasunik baden egiaztatzeko eta, esanguratsuak izan diren desberdintasunetan, halaber, post hoc analisiak egin dira, jakiteko desberdintasun horiek zein adin-talderen artean gertatzen diren. Azkenik, azterketa korrelazional bat aurrera eraman da, gelan aurkitzen den fa- 
milia-ereduen kopuruak beste aldagai guztiekin erlazio korrelazionala duen egiaztatzeko.

\section{EMAITZAK}

\section{Gelan dauden familia-ereduak}

Lehenik eta behin, gelan dauden familia-ereduak adierazi dituzte (ikusi 1. taula). Azpimarratu beharra dago 1.10. galderan (Ugalketa lagunduaren bidez jaiotako haurren familia) 4 pertsonak galdera-ikurra idatzi zutela.

1. taula

Familia-eredu bakoitzaren presentzia gelan (ehunekoetan)

\begin{tabular}{lll}
\hline \multicolumn{1}{c}{ Familia-ereduak } & \multicolumn{1}{c}{ Bai } & \multicolumn{1}{c}{ Ez } \\
\hline 1.01. Familia nuklearra (gurasoak eta seme-alabak) & $\% 100$ & $\% 0$ \\
1.02. Guraso bakarreko familia & $\% 54.2$ & $\% 45.8$ \\
1.03. Adopziozko familia & $\% 10.4$ & $\% 89.6$ \\
1.04. Familia homoparentala (sexu bereko bikotez osatua) & $\% 4.3$ & $\% 95.7$ \\
1.05. Familia berreraikia (seme-alabaren bat aldez au- & $\% 56.3$ & $\% 43.8$ \\
rretiko harreman batetik dator) & $\% 4.2$ & $\% 95.8$ \\
1.06. Harrera-familia & $\% 9.1$ & $\% 90.9$ \\
1.07. Etorkinen familia & $\% 81.3$ & $\% 18.8$ \\
1.08. Banatutako gurasoen familia & $\% 43.8$ & $\% 56.3$ \\
1.09. Familia hedatua (gurasoak eta aitona-amonak) & $\% 8.3$ & $\% 91.7$ \\
1.10. Ugalketa lagunduaren bidez jaiotako haurren familia & $\% 0$ & $\% 100$ \\
1.11. Subrogazioaren bidez sortutako familia & $\% 0$ & $\% 100$ \\
1.12. Beste batzuk & & \\
\hline
\end{tabular}

Aldagai honen datu deskribatzaileei dagokienez, nagusitzen den eredua familia nuklearra da, kasu guztietan aurkitu daiteke eta. Hala ere, zentro hauetan familia-aniztasuna badela esan daiteke; izan ere, 48 pertsona horien geletan batez beste 5 familia-eredu desberdin aurkitzen dira $(\bar{X}=4.83$, d.t=2.30).

Irakasleen formakuntza, aurreiritziak eta familia-aniztasunaren lanketa gelan. Materialen ezaguera

Bigarrenik, Likert eskala formatuan erantzundako 17 baieztapenen azterketa estatistikoa egin da. Horretarako, item bakoitzeko estatistiko-des- 
kribatzaileak (batezbestekoa, desbideratze tipikoa), zein erantzun bakoitzaren portzentajeak kalkulatu dira (ikusi 2. taula). Horrez gain, atal honen aldagaien puntuaketa totalak ere kalkulatu dira; horretarako, kontuan hartu da item batzuk kontrako norantzan puntuatzen direla eta errekodifikatu dira puntuak hori kalkulatu aurretik.

2. taula

\section{Irakasleei lotutako aldagaien datu deskribatzaileak}

\begin{tabular}{|c|c|c|c|c|c|}
\hline Baieztapena & $\bar{X}(\mathrm{~d} . \mathrm{t})$ & 1 & 2 & 3 & 4 \\
\hline $\begin{array}{l}\text { 2.01. Unibertsitatean familia-aniz- } \\
\text { tasunari buruzko formakun- } \\
\text { tza jaso nuen }\end{array}$ & $1.42(.77)$ & $\% 72.9$ & $\% 14.6$ & $\% 10.4$ & $\% 2.1$ \\
\hline $\begin{array}{l}\text { 2.02. Ikastetxean familia-anizta- } \\
\text { sunari buruzko formakuntza } \\
\text { jaso dut }\end{array}$ & $1.96(1.11)$ & $\% 50$ & $\% 16.7$ & $\% 20.8$ & $\% 12.5$ \\
\hline $\begin{array}{l}\text { 2.03. Ikastetxetik kanpo (ikasta- } \\
\text { roak...) familia-aniztasunari } \\
\text { buruzko formakuntza osaga- } \\
\text { rria jaso dut }\end{array}$ & $1.94(.932)$ & $\% 43.8$ & $\% 20.8$ & $\% 33.3$ & $\% 2.1$ \\
\hline $\begin{array}{l}\text { 2.04. Familia-aniztasunari buruzko } \\
\text { informazio gehiago behar da }\end{array}$ & $3.67(.56)$ & $\% 0$ & $\% 4.2$ & $\% 25$ & $\% 70.8$ \\
\hline
\end{tabular}

FORMAKUNTZA GUZTIRA $1.66(.51)$

2.05. Aita, ama eta seme-alabez osatutako familiak egokienak dira haurren garapenerako

2.06. Familian ama baino ez dagoenean, seme-alabek gizonezkoen eraginaren falta sumatzen dute

2.07. Eskolan ez da funtsezkoa bikote homosexualak agerikoak izatea (adibidez, ez da beharrezkoa haurren esko$1.55(.80) \quad \% 61.7 \quad \% 23.4 \quad \% \quad 12.8 \quad \% 2.1$ lako agiri ofizialetan bi ama dituela agertzea)

2.08. Etorkinek gure ohiturak barneratu behar dituzte

$1.74(1.18) \quad \% 67.4 \quad \% 8.7 \quad \% 6.5 \quad \% \quad 17.4$

$1.74(.85) \quad \% 48.9 \quad \% 29.8 \quad \% \quad 19.1 \quad \% 2.1$

2.09. Adoptatuak izan ziren haurrek eskolan zailtasun handiagoak dituzte 
Familia-aniztasunaren trataera Haur Hezkuntzako gelan

\begin{tabular}{cccccc}
\hline Baieztapena & $\bar{X}(\mathrm{~d} . \mathrm{t})$ & 1 & 2 & 3 & 4 \\
\hline AURREIRITZIAK GUZTIRA & $3.05(.59)$ & & & & \\
\hline
\end{tabular}

2.10. Familia-eredu ezberdinak ez dira gai batean bereziki landu $2.19(1.08) \quad \% 34 \quad \% 27.7 \quad \% 23.4 \quad \% 14.9$ behar

2.11. Familia-aniztasunak zailtasunak sortzen ditu

$1.38(.64) \quad \% 70.8 \% 20.8 \% 8.3 \quad \% 0$

2.12. Familia-aniztasuna gelan lantzea zaila da

$1.89(1.03) \quad \% 48.9 \quad \% 21.3 \quad \% 21.3 \quad \% \quad 8.5$

2.13. Irakasleen artean familiaeredu ezberdinak naturalta- $3.31(.903) \quad \% 2.1 \quad \% 22.9 \quad \% \quad 16.7 \quad \% 58.3$ sunez tratatzen dira

2.14. Familien inguruan hitz egiterakoan, familia-eredu desberdinei egiten diet erreferentzia

$3.27(.96) \quad \% 6.7 \quad \% \quad 15.6 \% 22.2 \% 55.6$

2.15. Gelan dauden familia-ereduak baino ez ditut lantzen

$2.07(1.20) \quad \% \quad 47.8 \quad \% \quad 17.4 \quad \% \quad 15.2 \quad \% \quad 19.6$

2.16. Edozein familia motak eskolan irudikatzen den familiarekin bere burua identifika$2.45(.95) \quad \% \quad 15.9 \quad \% \quad 38.6 \quad \% \quad 29.5 \quad \% \quad 15.9$ tzeko aukera du

2.17. Material didaktikoa lantzea zaila da, familia-aniztasunera $2.24(1.01) \quad \% 32.6 \quad \% \quad 19.6 \quad \% \quad 39.1 \quad \% 8.7$ egokitzeko

LANKETA GUZTIRA $\quad 3.06(.41)$

Taula honetan, bereziki deigarriak dira formakuntzarekin lotutako emaitzak; 48 parte-hartzaileek jakinarazten dute beren gai honetako formakuntza oso eskasa dela eta gehiago beharko luketela. Aurreiritziei dagokienez, ordea, badirudi ondo informatuta daudela orokorrean familia-eredu desberdinen benetako ezaugarriei buruz; honen salbuespena familia etorkinen kasua da, gure ohituretara egokitu behar direla uste baitute. Gelan gai honen lanketari dagokionez ere, emaitzak oso positiboak dira.

Azken honekin lotuta, profesional hauen ezagutza-mailaren azterketa egin da, familia-aniztasunarekin lotutako materialei dagokienez. Horretarako, familia-eredu ezberdinak islatzen zituzten material didaktikoak aurkeztu zaizkie eta, pauso honetan, material bakoitza zenbateko portzentajean aipatu duten aztertu da. Familia Milakolore proiek- 
tua \% 39.1ek ezagutzen du; Familium XX1 liburua, inork ez; Familia guztien aldeko ipuinak bilduma, \% 4.3k; Nuestra Casa liburua, \% 2.2k; Txinatik etorritako printzesa liburua, \% 23.9k; Paula tiene dos mamás liburua, \% 37k; Teo lagun baten etxean liburua, \% 28.9k; eta Buscando a Dory filma, \% 55.6k. Ikus daitekeenez, azken film hau eta Familia Milakolore materiala alde batera utzita, orokorrean material hauen ezagutza eskasa da.

\section{Zentroen prestutasuna}

\section{Eskolan dagoen material didaktikoa}

Egindako hurrengo azterketa hauxe izan da: grafiko bat egitea irakasleek adierazitako eskolako material didaktikoetan orokorrean agertzen den familia-ereduekin (ikusi 1. grafikoa). Grafikoan ikus daitekeen moduan, familia nuklearra da nagusi hezkuntza-baliabide guztietan: 36 pertsonak ipuin eta testuetan agertzen dela seinalatu dute; filmetan, 34 pertsonak; joko eta jostailuetan, 29k; antzerkietan, 26k; abestietan, 30ek; eta marrazki eta argazkietan, 28k. Beste familia-ereduen presentzia, aldiz, txikiagoa da.

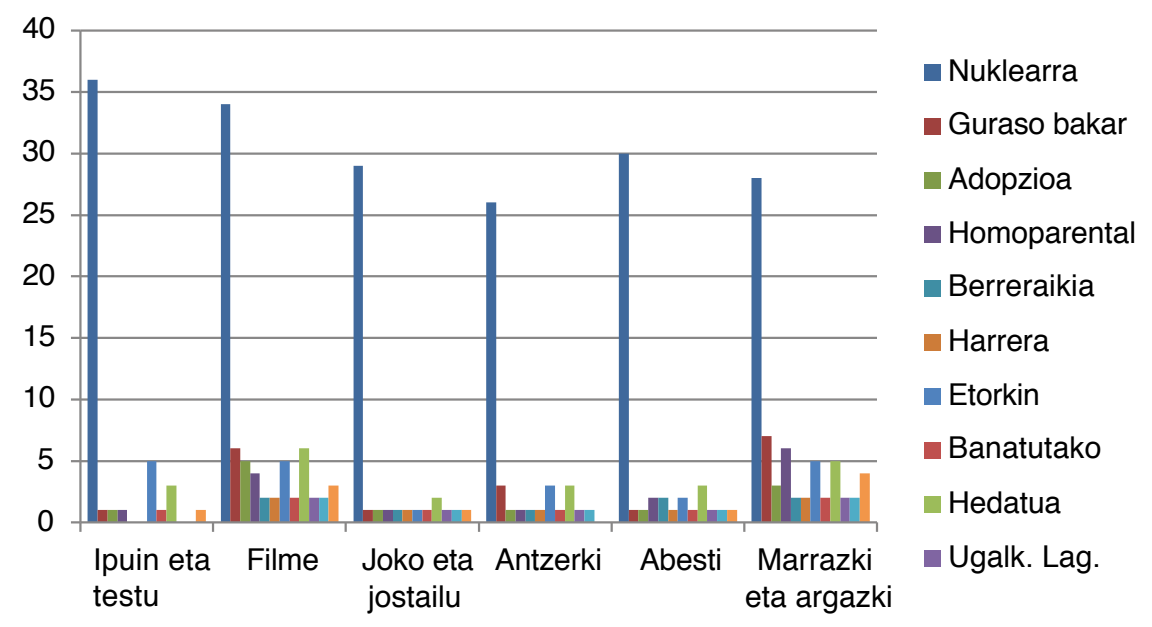

1. grafikoa

Eskolako material didaktikoetan agertzen den familia-eredua 
Eskolan aurrera eramaten diren ospakizun, jarduera eta protokoloak

Modu dikotomikoan (bai/ez) erantzun dute atal hau aztertzeko, eta parte-hartzaileen erantzunen portzentajeak kalkulatu dira (ikusi 3. taula).

3. taula

Eskolan aurrera eramaten diren ospakizunak, jarduerak eta protokoloak

\begin{tabular}{|c|c|c|}
\hline Itemak & Bai & Ez \\
\hline 5.1. Amaren eguna ospatzen dugu & $\% 6.7$ & $\% 93.3$ \\
\hline 5.2. Aitaren eguna ospatzen dugu & $\% 4.4$ & $\% 95.6$ \\
\hline $\begin{array}{l}\text { 5.3. Abenduan neguko oporrak ospatu beharrean, Gabonak } \\
\text { ospatzen ditugu }\end{array}$ & $\% 11.4$ & $\% 88.6$ \\
\hline 5.4. Gelan zuhaitz genealogikoak osatzen ditugu & $\% 4.7$ & $\% 95.3$ \\
\hline 5.5. Gelan jaiotzako fitxa betetzen dugu & $\% 23.8$ & $\% 76.2$ \\
\hline $\begin{array}{l}\text { 5.6. Familia-aniztasuna lantzeko protokolo edo lanerako } \\
\text { gida bat dugu }\end{array}$ & $\% 9.3$ & $\% 90.7$ \\
\hline
\end{tabular}

Ospakizunei dagokienez, deigarria da hiruretan (5.1, 5.2. eta 5.3) ezezko erantzunak jasotako adostasun altua. Jarduerei dagokienez (5.4. eta 5.5.), ia parte-hartzaileen laurdenak dio jaiotzako fitxa egiten duela gelan, portzentaje baxua baina kezkagarria. Eta, azkenik, atal honetako daturik kezkagarri edo negatiboena: parte-hartzaileen \%90ek baino gehiagok onartzen du ez duela familia-aniztasuna lantzeko protokolorik edo lanerako gidarik.

Adinaren eragina irakasleen formakuntzan, aurreiritzietan eta aniztasunaren lanketan

Aurrerago aipatu bezala, lan honen helburuetariko bat irakasle hauen erantzunean haien adinak eragina al duen jakitea da. Horregatik, 2. ataleko datuak hartu eta horiekin ANOVA bat aurrera eraman da, parte-hartzaileen adinaren araberako taldeak konparatuz. Konparatutako taldeak hauek izan dira: 21-30 urte, 31-40, 41-50 eta 51-60. Parte-hartzaileetako bat 61-70 tartean kokatzen da, baina azterketa hauetatik kendu da, ezin direlako pertsona bakar batekin konparaketak egin. ANOVAren emaitzak taula honetan ikus daitezke (ikusi 4. taula). 
Irakasleen formakuntza, aurreiritziak eta aniztasunaren lanketa adinaren arabera

\begin{tabular}{|c|c|c|c|c|c|c|}
\hline & \multicolumn{4}{|c|}{ Batezbestekoa adinka } & & \multirow[b]{2}{*}{ Sig } \\
\hline & $21-30$ & $31-40$ & $41-50$ & $51-60$ & & \\
\hline $\begin{array}{l}\text { 01. Unibertsitatean familia-aniztasunari bu- } \\
\text { ruzko formakuntza jaso nuen }\end{array}$ & 1.60 & 1.75 & 1.91 & 1.04 & 4.826 & .006 \\
\hline $\begin{array}{l}\text { 2.02. Ikastetxean familia-aniztasunari buruzko } \\
\text { formakuntza jaso dut }\end{array}$ & 1.69 & 1.25 & 2.18 & 2.09 & 1.636 & .195 \\
\hline $\begin{array}{l}\text { 2.03. Ikastetxetik kanpo (ikastaroak...) familia- } \\
\text { aniztasunari buruzko formakuntza osagarria } \\
\text { jaso dut }\end{array}$ & 2.20 & 1.75 & 2.45 & 1.65 & 2.266 & .094 \\
\hline $\begin{array}{l}\text { 2.04. Familia-aniztasunari buruzko informazio } \\
\text { gehiago behar da }\end{array}$ & 3.60 & 3.87 & 3.82 & 3.52 & 1.175 & .330 \\
\hline FORMAKUNTZA GUZTIRA & 1.70 & 1.47 & 1.93 & 1.57 & 1.749 & .171 \\
\hline $\begin{array}{l}\text { 2.05. Aita, ama eta seme-alabez osatutako fami- } \\
\text { liak haurren garapenerako egokienak dira }\end{array}$ & 1.20 & 1.00 & 1.64 & 1.82 & 2.665 & .060 \\
\hline $\begin{array}{l}\text { 2.06. Familian ama baino ez dagoenean, seme- } \\
\text { alabek gizonezkoen eraginaren falta suma- } \\
\text { tzen dute }\end{array}$ & 1.40 & 1.13 & 2.00 & 1.95 & 2.766 & .054 \\
\hline $\begin{array}{l}\text { 2.07. Eskolan ez da funtsezkoa bikote homosexua- } \\
\text { lak agerikoak izatea (adibidez, ez da beha- } \\
\text { rrezkoa haurren eskolako agiri ofizialetan bi } \\
\text { ama dituela agertzea) }\end{array}$ & 1.00 & 1.25 & 2.27 & 1.82 & 1.830 & .157 \\
\hline $\begin{array}{l}\text { 2.08. Etorkinek gure ohiturak barneratu behar } \\
\text { dituzte }\end{array}$ & 2.00 & 2.2 & 3.27 & 2.68 & 3.714 & .019 \\
\hline $\begin{array}{l}\text { 2.09. Adoptatuak izan ziren haurrek eskolan } \\
\text { zailtasun handiagoak dituzte }\end{array}$ & 2.00 & 2.00 & 2.36 & 1.77 & .869 & .465 \\
\hline AURREIRITZIAK GUZTIRA & 3.47 & 3.47 & 2.69 & 2.98 & 4.054 & .014 \\
\hline $\begin{array}{l}\text { 2.10. Familia-eredu ezberdinak ez dira gai ba- } \\
\text { tean bereziki landu behar }\end{array}$ & 2.80 & 2.13 & 2.00 & 2.23 & .646 & .590 \\
\hline 2.11. Famil & 1.00 & 0 & 1.36 & 1.43 & .716 & .548 \\
\hline 2.12. Familia-anizta & 1.00 & 1.50 & 2.18 & 2.04 & 1.927 & .140 \\
\hline $\begin{array}{l}\text { 2.13. Irakasleen artean familia-eredu ezberdinak } \\
\text { naturaltasunez tratatzen dira }\end{array}$ & 3.60 & 3.75 & 3.00 & 3.26 & 1.256 & .302 \\
\hline $\begin{array}{l}\text { 2.14. Familien inguruan hitz egiterakoan, familia- } \\
\text { eredu desberdinei egiten diet erreferentzia }\end{array}$ & 3.80 & 3.13 & 3.27 & 3.15 & .640 & .594 \\
\hline $\begin{array}{l}\text { 2.15. Gelan dauden familia-ereduak baino ez di- } \\
\text { tut lantzen }\end{array}$ & 1.00 & 2.00 & 1.45 & 2.43 & 2.875 & .048 \\
\hline $\begin{array}{l}\text { 2.16. Edozein familia motak eskolan irudikatzen } \\
\text { den familiarekin bere burua identifikatzeko } \\
\text { aukera du }\end{array}$ & 2.80 & 2.50 & 2.40 & 2.35 & .294 & .829 \\
\hline $\begin{array}{l}\text { 2.17. Material didaktikoa lantzea zaila da, fami- } \\
\text { lia-aniztasunera egokitzeko }\end{array}$ & 2.00 & 1.75 & 2.60 & 2.35 & 1.224 & .313 \\
\hline LANKETA GUZTIRA & 3.58 & 3.19 & 2.96 & 2.96 & 2.782 & .056 \\
\hline
\end{tabular}


Taulan ikus daitekeenez, hainbat itemetan adinaren araberako desberdintasun esanguratsuak aurkitu dira, gutxi batzuetan izan bada ere. Zehazki, 2.1. (Unibertsitatean familia-aniztasunari buruzko formakuntza jaso nuen), 2.8. (Etorkinek gure ohiturak barneratu behar dituzte) eta 2.15 (Gelan dauden familia-ereduak baino ez ditut lantzen) itemetan, zein aurreiritzien puntuaketa totalean.

Desberdintasunak ikusita, jakin behar da zein adin-tarteren artean gertatzen diren desberdintasun horiek. Horretarako, ezberdintasun esanguratsuak erakusten dituzten itemak/puntuaketak hartu eta horiekin post hoc azterketak egin dira. Hauek aurrera eraman eta gero, ikusi da 2.1. itemean (Unibertsitatean familia-aniztasunari buruzko formakuntza jaso nuen) desberdintasun estatistikoki esanguratsua $(\mathrm{p}=.007)$ 41-50 urte bitarteko $(\bar{x}=1.91)$ eta 51-60 ( $\bar{x}=1.04)$ urte bitartekoen artean gertatzen dela. Hau da, 51-60 urte bitartekoek 41-50 bitartekoek baino formakuntza gutxiago jaso dutela unibertsitatean.

2.8. itemean (Etorkinek gure ohiturak barneratu behar dituzte), bi desberdintasun esanguratsu aurkitu dira. Alde batetik, 21-30 urte bitartekoek $(\overline{\mathrm{x}}=2.00)$ 41-50 urte bitartekoek $(\overline{\mathrm{x}}=3.27)$ baino baxuago puntuatu dute $(\mathrm{p}=.046)$. Era berean, 31-40 urte bitartekoek $(\bar{x}=2.25)$ 41-50 urte bitartekoek ( $\overline{\mathrm{x}}=3.27)$ baino baxuago puntuatu dute $(\mathrm{p}=.043)$. Laburbilduz, 41-50 urte bitartekoak, kasu honetan, urrunago agertu dira aniztasunaren normalizazio horretatik 21-30 eta 31-40 urte bitartekoekin alderatuz.

Aurreiritzien puntuaketa totalari dagokionez ere, desberdintasun esanguratsu bat aurkitu da ( $\mathrm{p}=.016)$ : 31-40 urte bitartekoek $(\overline{\mathrm{x}}=3.47)$ 41-50 urte bitartekoek $(\bar{x}=2.69)$ baino altuago puntuatu dute. Kasu honetan, puntuaketa totala kalkulatzeko item batzuk errekodifikatu direla kontuan hartuz, puntuaketa altu batek esan nahi du aniztasuna hobeto lantzen dela aurreiritzi gutxiagorekin. Horren harira, 31-40 urte bitartekoak gutxiago erortzen dira aurreiritzietan 41-50 urte bitartekoak baino.

Azkenik, 2.15 itemari dagokionez (Gelan dauden familia-ereduak baino ez ditut lantzen), post hoc azterketak egin eta gero ikusi da adin-tarteak binaka konparatzean ez dagoela haien arteko ezberdintasun esanguratsurik.

\section{Adinaren eragina materialen ezagutzan}

Gorago ikusi ahal izan da proposatzen zitzaizkien materialen artean zeintzuk ezagutzen dituzten (eta haiek ere aukera izan dute material gehiago aipatzeko). Kasu honetan, haien erantzunak hartu eta, portzentajeak kalkulatu beharrean, puntuaketa total bat kalkulatu da. Hain zuzen ere, ezagutzen duten material kopurua adierazten duen puntuaketa kuantitatiboa.

Puntuaketa hau hartuta, ANOVA bat aurrera eraman da, adin-tarteen araberako desberdintasun esanguratsuak dauden egiaztatzeko. ANOVAren emaitza ez da estatistikoki esanguratsua izan $(p=.070)$; beraz, ezin da esan adinaren arabera materialen ezagutza desberdina denik. 


\section{Familia-eredu kopurua eta aniztasunaren aurreko erantzuna}

Azkenik, ikertu nahi izan da ea eskola hauetan existitzen den familiaeredu kopurua lotuta dagoen 48 parte-hartzaileek ematen duten erantzunarekin, bai eta eskola hauetan egiten den lanketarekin ere. Horregatik, azterketa korrelazional bat aurrera eraman da (ikusi 5. taula), non, alde batetik, familia -eredu kopurua eta, bestetik, aldagai indibidual zein instituzional hauek kokatu diren, haien arteko norabide biko erlazioak esanguratsuak diren konprobatzeko.

\section{5.taula}

Familia-ereduen kopuruaren eta beste aldagaien arteko korrelazioak

\begin{tabular}{|c|c|c|c|c|c|c|c|c|c|c|c|c|}
\hline & & $\begin{array}{l}\text { Tot_ } \\
\text { famiere }\end{array}$ & $\begin{array}{l}\text { Tot_ } \\
\text { form }\end{array}$ & $\begin{array}{l}\text { Tot__ } \\
\text { aurrei }\end{array}$ & $\begin{array}{c}\text { Tot__ } \\
\text { lanket }\end{array}$ & $\begin{array}{c}\text { Mat_ } \\
\text { ezag_tot }\end{array}$ & $\begin{array}{l}5.1 . \\
\text { item }\end{array}$ & $\begin{array}{l}2.2 . \\
\text { item }\end{array}$ & $\begin{array}{l}2.3 . \\
\text { item }\end{array}$ & $\begin{array}{l}2.4 . \\
\text { item }\end{array}$ & $\begin{array}{l}2.5 . \\
\text { item }\end{array}$ & $\begin{array}{l}2.6 . \\
\text { item }\end{array}$ \\
\hline \multirow{2}{*}{$\begin{array}{l}\text { Total__ } \\
\text { famiere }\end{array}$} & $\mathrm{r}$ & 1 &, $401 * *$ & ,147 &, $323 *$ &, $327 *$ & 051 & 057 &,- 020 &,- 132 & ,203 &, $328 *$ \\
\hline & Sig. & & ,006 & ,359 & ,048 & ,034 & ,745 & ,716 & ,902 & ,412 & ,210 & ,037 \\
\hline \multirow{2}{*}{$\begin{array}{l}\mathrm{TOT}_{-} \\
\text {form }\end{array}$} & $\mathrm{r}$ & & 1 &,- 116 & ,214 & ,230 &, $363^{*}$ &, $470 * *$ & , 149 &,- 009 & ,003 &, $436 * *$ \\
\hline & Sig. & & & ,459 & ,190 & ,134 & ,014 & ,001 &, 335 & ,956 & ,987 & ,003 \\
\hline \multirow{2}{*}{$\begin{array}{l}\text { TOT }_{-} \\
\text {aurrei }\end{array}$} & $\mathrm{r}$ & & & 1 &, $428 * *$ & ,112 &,- 123 &,- 123 & ,032 & ,178 & ,049 &,- 234 \\
\hline & Sig. & & & & ,008 & ,490 & ,443 & ,443 & 844 & ,271 & ,765 & 151 \\
\hline \multirow{2}{*}{$\begin{array}{l}\text { TOT_ } \\
\text { lanket }\end{array}$} & $\mathrm{r}$ & & & & 1 &, $363 *$ & ,219 & ,219 & ,007 & ,006 &,- 145 &,- 106 \\
\hline & Sig. & & & & & ,027 & ,193 & ,193 & ,966 & ,972 & ,415 &, 537 \\
\hline \multirow{2}{*}{$\begin{array}{l}\text { Mat_ } \\
\text { ezag_- } \\
\text { tot }\end{array}$} & $\mathrm{r}$ & & & & & 1 &,- 077 & ,083 &,- 121 &,- 181 &,- 023 & ,196 \\
\hline & Sig. & & & & & & ,623 & ,596 & ,439 & ,257 & ,889 & ,219 \\
\hline \multirow{2}{*}{$\begin{array}{l}5.1 . \\
\text { item }\end{array}$} & $\mathrm{r}$ & & & & & & 1 &, $807 * *$ & ,099 &,- 050 &,- 149 &, 225 \\
\hline & Sig. & & & & & & & ,000 &, 526 & ,753 &, 352 & ,152 \\
\hline \multirow{2}{*}{$\begin{array}{l}5.2 . \\
\text { item }\end{array}$} & $\mathrm{r}$ & & & & & & & 1 & ,080 &,- 050 &,- 120 &, $308^{*}$ \\
\hline & Sig. & & & & & & & & ,610 &, 753 & ,455 & ,047 \\
\hline \multirow{2}{*}{$\begin{array}{l}5.3 . \\
\text { item } \\
\end{array}$} & $\mathrm{r}$ & & & & & & & & 1 &,- 263 & ,044 &, 119 \\
\hline & Sig. & & & & & & & & & ,092 & ,789 & ,452 \\
\hline \multirow{2}{*}{$\begin{array}{l}5.4 . \\
\text { item }\end{array}$} & $\mathrm{r}$ & & & & & & & & & 1 & , 149 &,- 074 \\
\hline & Sig. & & & & & & & & & & ,367 & ,644 \\
\hline \multirow{2}{*}{$\begin{array}{l}5.5 . \\
\text { item }\end{array}$} & $\mathrm{r}$ & & & & & & & & & & 1 &,- 005 \\
\hline & Sig. & & & & & & & & & & & 976 \\
\hline \multirow{2}{*}{$\begin{array}{l}5.6 . \\
\text { item }\end{array}$} & $\mathrm{r}$ & & & & & & & & & & & 1 \\
\hline & Sig. & & & & & & & & & & & \\
\hline
\end{tabular}


Taulan ikus daitekeen bezala, aldagai indibidualei dagokienez, familiaereduen kopurua lotuta dago irakasle hauen formakuntzarekin, gelan egiten duten lanketarekin eta materialen ezagutzarekin. Hau da, familia-eredu kopuru gehiago duten irakasleek formakuntza gehiago dute, gelan gehiago lantzen dute gai hau eta material gehiago ezagutzen dituzte. Zentroarekin lotutako aldagaiei dagokienez, erlazio esanguratsu bakarra 5.6 itemarekin da (Familia-aniztasuna lantzeko protokolo edo lanerako gida bat dugu).

\section{ONDORIOAK}

Haur Hezkuntzako irakasleei zuzendutako galdetegiaren emaitzek eta marko teorikoan aztertutako informazioak lanaren helburu nagusiak betetzea ahalbidetu dute. Hots, lan enpiriko honen bidez askotariko familia-ereduek eskolan zer presentzia duten ezagutu da, baita eskolatik familia-aniztasunari ematen zaion erantzuna aztertu ere.

Helburu zehatzetan zentratuz, esan daiteke gehien agertzen den eredua oraindik familia nuklearrak izaten jarraitzen badu ere argi ikusten dela ez dela dagoeneko eredu bakarra. Batez besteko eredu kopurua 5 ingurukoa da eta aniztasun handiena duen zentroan 16 eredu agertzen dira; beraz, gero eta familia-aniztasun handiagoa dagoela baiezta daiteke, aurreko egile batzuek aurkitutakoaren norabidean (Abril eta Peinado, 2018; Aguado, 2010; Mujika, 2005).

Beste gauza bat da aniztasun horren aurrean hezkuntza-sistema ondo erantzuten ari den egiaztatzea, maila indibidualean zein maila instituzionalean.

Alde batetik, ikerketaren bidez lortutako emaitzei erreparatuta, irakasleek familia-aniztasunari buruz jasotako formakuntza urria da. Ez hori bakarrik, gaiari buruzko informazio gehiago behar dela adierazi dute. Hori bat dator beste egile batzuek aurkitutakoarekin (Abril eta Peinado, 2018; Triana et al., 2019) eta gauzak aldatzearen beharra aditzera ematen du. Gai honi buruzko formakuntza areagotu beharko litzateke, ez bakarrik dagoeneko lanean ari diren profesionalen kasuan. Interesgarria izango litzateke formakuntza hori garaiz iristea, pertsona hauek lan-mundura heldu baino lehen.

Aurreiritzei dagokienez, orokorrean beren ideiak argi dauzkate eta ez dira topikoetan erortzen. Beraz, formakuntza-maila altuagoa izan ahal bada ere, batez ere maila praktikoan, badirudi ezagutza-mailan gaia ezagutzen dutela. Honen salbuespena familia etorkinen gaia da, zeinetan aurreiritzi arriskutsuak agertzen diren. Zentzu honetan, eta gurea inguru gero eta multikuluralagoa dela kontutan hartuz, aurreiritzi horiekin bukatzeko formakuntza-saioak beharrezkoak izango lirateke profesional hauentzat. Izan ere, haien aurreiritziek ume hauen eta haien familien bizipenetan eragin handia izan dezakete (Triana et al., 2019).

Zentroei dagokienez, esan daiteke ez daudela guztiz prest familia-aniztasunaren gai honi egokiro aurre egiteko. Gero eta argiago ikusten da, zorio- 
nez, aitaren eguna, amaren eguna eta horrelako ospakizunek ez diotela erantzuten eskolan bizi den aniztasun horri. Hala eta guztiz ere, horiek bezalako egun zehatzetatik haratago joanda, parte-hartzaileen gehiengoak onartzen du bere zentroan ez dagoela protokolorik edo jarduteko gidarik. Aguadok (2010) dioenez, lanerako gida izatea lagungarria izan daiteke familiaren gaia ikuspuntu zabal batetik lantzeko. Are gehiago, zailtasunen aurrean irtenbideak bilatzeko erabilgarria izan daiteke. Halaber, interesgarria izango litzateke, protokoloak edota gidak prestatu eta lantzeaz gain, eskoletan familia-aniztasunaren lanketa areagotzea eta normalizatzea, esate baterako, proiektuka lan eginez, egile batzuek proposatzen duten modura (Balongo eta Mérida, 2017; Hik Hasi, 2004; González, 2009).

Parte-hartzaileen adinean zentratuz, eta hipotetizatu bezala, aldagai horrek badu eragina ikertutako hainbat aspektutan. Desberdintasunak aurkitutako gai gehienetan, 41-50 urte bitartekoek izan dira besteekiko ezberdinak izan direnak: gutxiago formatuak, aurreiritzi gehiago dutenak, eta abar. Honek bat egiten du beste egile batzuek aurkitutakoarekin (Triana et al., 2019), haien kasuan gehien desberdintzen zirenak gazteak izan arren. Edozein modutan, honek aditzera ematen diguna da aurretik aipatutako beharrak esanguratsuagoak direla adin-tarte honetan. Beraz, guztiekin orokorrean, baina hauekin bereziki, gauzak aldatzen hasi beharko lirateke, zentroetan formakuntza gehiago eskainiz, edota aurreiritzi horiek hausten saiatuz.

Familia-eredu kopuruari so eginez, aurkitu da hau lotuta dagoela profesionalek eta haien zentroek egiten dutenarekin. Hau da, familia-ereduen kopuru handiagoa duten zentroetan, bertako profesionalek gaia gelan gehiago lantzen dute, edo formatuago daude eta, era berean, instituzioak berak ere gauzak modu desberdin batean egiten ditu. Aurkikuntza hau bi norabide desberdinetan interpreta daiteke: batetik, modu positiboan, izan ere, aniztasuna gorantz doan heinean, zentro eta profesional hauek errealitate horretara egokituz eta ondo erantzunez joan dira; baina, bestetik, eta gorago aipatu bezala, ez genuke itxaron behar hori gertatu arte eta, gure gizartea eta gure gelak gero eta anizkoitzagoak izango direla jakinda, horri aurrea hartu eta egoeraren aurrean aurkitu baino askoz lehenago prest egon beharko lirateke zentro eta profesional hauek. Berriro ere, formakuntza on eta garaiko baten garrantzia argi ikusten da. Familia errealitate sozial aldakorra da (Miret, 2016) eta eskola ere aldatuz joan beharko da, elkarlanean modu eraginkor eta osasuntsu batean lan egiten jarraitu ahal izateko. Azken finean, familia-eredua ez da garrantzitsuena, bizi-kalitatea baizik (Golombok, 2006), eta azken honetan zeresan handia dute ume hauekin lanean arituko diren Haur Hezkuntzako profesionalek; haien esku dago haien bizi -kalitatea eta ongizatea bermatzea.

Lanari bukaera eman aurretik, ezinbestekoa da honen mugen inguruko hausnarketa egitea. Muga horien artean, aipatu beharra dago laginaren adierazgarritasuna. Zentzu horretan, etorkizunera begira, lagina handitzea 
egokia izango litzateke, askotariko emaitzak eta fidagarriagoak direnak lortzeko aukera izateko. Bestalde, neurketa-tresnaren fidagarritasuna ere mugatua da. Ad hoc sortutako galdetegi bat erabiltzeak lanaren helburuetara zuzendutako datu ugari jasotzea ahalbidetu arren, mugak ere baditu. Dena den, lan honetan egindako datu-jasoketa gure inguruaren egoera ezagutzeko lehenengo hurbilpen modura ikus daiteke eta hurrengo jasoketetan tresna hobetu eta estatistikoki balidatu ahal izateko balioko du.

Hortaz, nahiz eta lagina txikia izan eta erabilitako tresnak mugak izan, ikerketa hau oso baliagarria izan da familia-aniztasuna eskolan nola tratatzen den aztertzeko eta irakasleen jarrerak eta iritziak ezagutzeko. Era berean, parte-hartzaileek ere lanaren garrantzia azpimarratu dute. Etorkizunari begira, ikerketa honek gaian sakontzeko aukera ematen du; egungo eskoletan familia-aniztasunaren egoera ezagutzea ahalbidetzeaz gain, galdera berriak planteatu dituelako.

Ikerketa honen bidez eskolak familia-aniztasunaren aurrean duen jarrera aztertzeko bidea irekitzea espero da. Alde batetik, familia-aniztasuna eskoletan errealitatea dela baieztatu delako. Bestetik, irakasleek familia-aniztasunaren aldeko jarrerak izan arren, eskoletan oraindik gabezia batzuk antzeman izan direlako: familia-eredu ezberdinak islatzen dituzten hezkuntza-baliabideen gabezia eta gaiaren inguruko ezagutza falta, batez ere.

\section{ERREFERENTZIAK}

Abril, A., eta Peinado, M. (2018). Nuevos horizontes familiares: Una reflexión en la formación inicial del profesorado. Profesorado. Revista de Currículum y Formación del Profesorado, 22(1), 159-176.

Aguado, L. (2010). Familia ereduak gaurko eskolan. Tantak, 22(1), 127-148.

Aldeas Infantiles SOS (2018). Qué es una familia de acogida. 2019-01-24an berreskuratua, hemendik: https://www.aldeasinfantiles.es/actualidad/que-es-unafamilia-de-acogida

Arranz, E., Olabarrieta, F., Galende, N., Manzano, A., eta Martín, J. L. (2010). Familias recurrentes a la reproducción asistida y familias múltiples. In E. Arranz eta A. Oliva (koord.), Desarrollo psicológico en las nuevas estructuras familiares (89-99). Madril: Pirámide.

Balongo, E., eta Mérida, R. (2017). Incluir la diversidad familiar en las aulas infantiles a través de los proyectos de trabajo. Profesorado. Revista de Currículum y Formación de Profesorado, 21(2), 231-251.

Bronfenbrenner, U. (2001). The bioecological theory of human development. In N. Smelser eta P. Baltes (Ed.), International encyclopedia of the social and behavioural sciences, 10 (6963-6970). New York: Elsevier.

Collet, J., eta Tort, A. (2017). Escuela, familias y comunidad. Bartzelona: Octaedro.

Cortés, M. R., eta Cantón, J. (2010). Familias monoparentales. In E. Arranz eta A. Oliva (koord.), Desarrollo psicológico en las nuevas estructuras familiares (35-50). Madril: Pirámide. 
Eusko Jaurlaritza (2014). HEZIBERRI 2020. Hezkuntza-Eredu Pedagogikoaren Markoa. 2020-09-07an berreskuratua, hemendik: https://www. euskadi.eus/contenidos/informacion/heziberri_2020/eu_heziberr/adjuntos/ Heziberri_2020_e.pdf

Hik Hasi (2004). Familia ereduak eta eskola. Hik Hasi, 84, 8-13. Garrido, M. (1995). Estructura, relaciones y funciones de la familia. In A. Espina, B. Pumar eta M. Garrido (Konp.). Problemáticas familiares actuales y terapia familiar (17-55). Valentzia: Promolibro.

Goldberg, A., Black, K., Sweeney, K., eta Moyer, A. (2017). Lesbian, gay, and heterosexual adoptive parents' perceptions of inclusivity and receptiveness in early childhood education settings. Journal of Research in Childhood Education, 31(1), 141-159.

Golombok, S. (2006). Modelos de familia ¿qué es lo que de verdad cuenta?. Bartzelona: Graó.

González, M. M. (2009). Nuevas familias, nuevos retos para la investigación y la educación. Cultura y educación, 21(4), 381-389.

González, M. M., eta Triana, B. (2001). Dibortzioa, gurasobakartasuna eta bikotetze berriak. In M. J. Rodrigo eta J. Palacios (koord.), Familia eta giza garapena (357-379). Bilbo: Udako Euskal Unibertsitatea.

Grau, C., eta Fernández, M. (2015). Nuevas estructuras familiares: implicaciones para el sistema educativo. Valentzia: Valentziako Unibertsitatea.

Iglesias de Ussel, J. (2001). Espainiako familiak Europan. In M. J. Rodrigo eta J. Palacios (koord.), Familia eta giza garapena (85-105). Bilbo: Udako Euskal Unibertsitatea.

INE (2014). Encuesta Continua de Hogares. Año 2013. Datos Provisionales. Notas de prensa. 2020-09-07an berreskuratua, hemendik: https://ine.es/prensa/np837.pdf

INE (2019). Nacimientos ocurridos en España. Año 2019. Datos Provisionales. Notas de prensa. 2020-09-07an berreskuratua, hemendik: https:/www.ine.es/ dyngs/INEbase/es/operacion.htm?c=Estadistica_C\&cid=1254736177007\&me nu=ultiDatos\&idp $=1254735573002$

INE (2020). Encuesta Continua de Hogares (ECH). Año 2019. Datos Provisionales. Notas de prensa. 2020-09-07an berreskuratua, hemendik: https://ine.es/ prensa/ech_2019.pdf

Kallinsky, E. (2010). Familia, escuela y comunidad. Rivista Italiana di Educazione Familiare, 2, 45-56.

Koerner, M. E., eta Hulsebosch, P. (1996). Preparing teachers to work with children of gay and lesbian parents. Journal of Teacher Education, 47(5), 347-354.

Ley 14/2006, maiatzaren 26koa, sobre técnicas de reproducción humana asistida. BOE, 126, 2006ko maiatzaren 27koa.

Ley Orgánica 8/2013, abenduaren 9koa, para la Mejora de la Calidad Educativa (LOMCE) (2013). BOE, 295, abenduaren 10ekoa.

López-Abadía, I. (CEISH) (2011). El consentimiento informado en la investigación universitaria con seres humanos. Leioa: Vicerrectorado de Investigación de la UPV/EHU.

López, F., Díez, M., Morgado, B., eta González, M. M. (2008). Educación infantil y diversidad familiar. Revista de Educación, 10, 111-122.

López-Larrosa, S. (2009). El sistema familiar ante el divorcio: factores de riesgo y protección y programas de intervención. Cultura y Educación, 21(4), 391-402. 
López-Larrosa, S. (2016). La relación familia-escuela: Guía práctica para profesionales. Madril: Editorial CCS.

López-Larrosa, S., eta Escudero, V. (2003). Familia: evaluación, investigación e intervención. Madril: Editorial CCS.

Miret, P. (2016). Cambios en los hogares y en la familia: España en el siglo XXI en el contexto europeo. Panorama Social, 23, 91-107.

Morgado, B., Jiménez, I., eta González, M. M. (2009). Ideas del profesorado de primaria acerca de la diversidad familiar. Cultura y educación, 21(4), 441-452.

Mujika, I. (2005). Modelos familiares y cambios sociales: La homoparentalidad a debate. Bilbo: ALDARTE.

Navarrete, C. (2010). La representación de la familia nuclear y la familia extensa en seis historias de vida de habitantes de la calle en Bogotá (Lizentziatura-tesia). 2019-01-24an berreskuratua, hemendik: https://repository.javeriana.edu. $\mathrm{co} / \mathrm{bitstream} / \mathrm{handle} / 10554 / 5884 /$ tesis582.pdf?sequence $=1$

Nuclear family (d.b.). In Cambridge Academic Content Dictionary. 2019-01-24an berreskuratua, hemendik: https://dictionary.cambridge.org/es/diccionario/ingles/nuclear-family

Nuclear family (d.b). In Encyclopedia Britannica. 2019-01-24an berreskuratua, hemendik: https://www.britannica.com/topic/nuclear-family

Oliva, A., eta Palacios, J. (2001). Familia eta eskola: gurasoak eta irakasleak. In M. J. Rodrigo eta J. Palacios (koord.), Familia eta giza garapena (321-337). Bilbo: Udako Euskal Unibertsitatea.

Oliva, A., Parra, A., eta Antolín, L. (2010). Familias reconstituidas. In E. Arranz eta A. Oliva (koord.), Desarrollo psicológico en las nuevas estructuras familiares (69-87). Madril: Pirámide.

Oliva, A., Parra, A., Antolín, L., Arranz, E., Martín, J. L., eta Lamb, M. (2010). Diversidad familiar y desarrollo psicológico: un estudio pionero realizado en España. In E. Arranz eta A. Oliva (koord.), Desarrollo psicológico en las nuevas estructuras familiares (143-157). Madril: Pirámide.

Pedro-Carroll, J. A. (2005). Fostering resilience in the aftermath of divorce. The role of evidence-based programs for children. Family Court Review, 43, 52-64.

Poó, F., Ledesma, R., eta Montes, S. (2010). Propiedades psicométricas de la escala de deseabilidad social del conductor. Redalyc, 9(2), 299-310.

Rodríguez-Ruiz, B., Martínez-González, R. A., eta Rodrigo, M. J. (2016). Dificultades de las Familias para Participar en los Centros Escolares. Revista Latinoamericana de Educación Inclusiva, 10(1), 79-98.

Richard, H. (2005). Stability and change in US prospective teachers' beliefs and decisions about diversity and learning to teach. Teaching and Teacher Education, 21, 767-786.

Taberner, J. (2012). Familia y educación: Instituciones reflexivas en una sociedad cambiante. Madril: Dykinson.

Terrén, E. (2007). Familia, escuela e inmigración. Migraciones, 22, 9-46.

Triana, B., eta Rodrigo, M. J. (2010). Modelos y estrategias de intervención ante la diversidad familiar. In E. Arranz eta A. Oliva (Koord.), Desarrollo psicológico en las nuevas estructuras familiaress (121-142). Madril: Pirámide.

Triana, B., Ceballos, E. M., eta Rodríguez, J. A. (2019). Expectativas del futuro profesorado de Educación Infantil y Primaria sobre el desarrollo infantil en distintas estructuras familiares. Aula Abierta, 48(1), 67-76. 


\section{ERANSKINAK}

\section{1. eranskina: Haur Hezkuntzako irakasleei banatutako galdetegia}

\section{Galdetegia}

Adina:
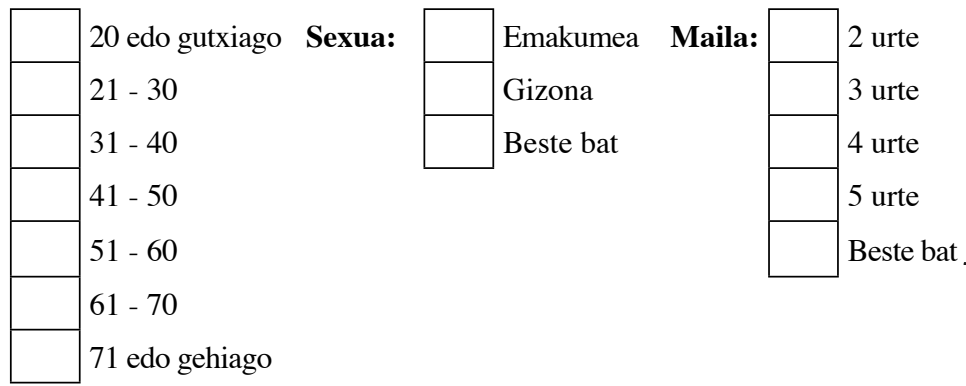

1. Adierazi zein neurritan zauden ados edo ez ados ondoko baieztapenekin (oharren bat idatzi nahi izatekotan, baieztapen bakoitzaren azpian espazioa daukazu):

\begin{tabular}{|c|c|c|c|}
\hline $\mathbf{1}$ & $\mathbf{2}$ & $\mathbf{3}$ & $\mathbf{4}$ \\
Guztiz desados & Zertxobait desados & Zertxobait ados & Guztiz ados \\
\hline
\end{tabular}

\begin{tabular}{|c|c|c|c|c|}
\hline $\begin{array}{l}\text { 1.1. Unibertsitatean familia aniztasunari buruzko forma- } \\
\text { kuntza jaso nuen }\end{array}$ & 1 & 2 & 3 & 4 \\
\hline $\begin{array}{l}\text { 1.2. Ikastetxean familia aniztasunari buruzko formakun- } \\
\text { tza jaso dut }\end{array}$ & 1 & 2 & 3 & 4 \\
\hline $\begin{array}{l}\text { 1.3. Ikastetxetik kanpo (ikastaroak...) familia aniztasunari } \\
\text { buruzko formakuntza osagarria jaso dut }\end{array}$ & 1 & 2 & 3 & 4 \\
\hline $\begin{array}{l}\text { 1.4. Familia aniztasunari buruzko informazio gehiago } \\
\text { behar da }\end{array}$ & 1 & 2 & 3 & 4 \\
\hline $\begin{array}{l}\text { 1.5. Aita, ama eta seme-alabez osatutako familiak haurren } \\
\text { garapenerako egokienak dira }\end{array}$ & 1 & 2 & 3 & 4 \\
\hline
\end{tabular}




\begin{tabular}{|c|c|c|c|c|c|}
\hline & $\begin{array}{l}\text { Familian ama baino ez dagoenean, seme-alabek gi- } \\
\text { zonezkoen influentzia faltan botatzen dute }\end{array}$ & 1 & 2 & 3 & 4 \\
\hline 1.7. & $\begin{array}{l}\text { Eskolan ez da funtsezkoa bikote homosexualak age- } \\
\text { rikoak izatea (adib. Ez da beharrezkoa haurren esko- } \\
\text { lako agiri ofizialetan bi ama dituela agertzea) }\end{array}$ & 1 & 2 & 3 & 4 \\
\hline 1.8 . & Etorkinek gure ohiturak barneratu behar dituzte & 1 & 2 & 3 & 4 \\
\hline 1.9. & $\begin{array}{l}\text { Adoptatuak izan ziren haurrek eskolan zailtasun } \\
\text { handiagoak dituzte }\end{array}$ & 1 & 2 & 3 & 4 \\
\hline 1.10 . & $\begin{array}{l}\text { Familia-eredu ezberdinak ez dira gai batean bereziki } \\
\text { landu behar }\end{array}$ & 1 & 2 & 3 & 4 \\
\hline 1.11 & Familia aniztasunak zailtasunak sortzen ditu & 1 & 2 & 3 & 4 \\
\hline 1.12 & $\begin{array}{l}\text { Irakasleen artean familia-eredu ezberdinak natural- } \\
\text { tasunez tratatzen dira }\end{array}$ & 1 & 2 & 3 & 4 \\
\hline 1.13. & Familia aniztasuna gelan lantzea zaila da & 1 & 2 & 3 & 4 \\
\hline 1.14 & $\begin{array}{l}\text { Familien inguruan hitz egiterakoan, familia-eredu } \\
\text { desberdinei egiten diet erreferentzia }\end{array}$ & 1 & 2 & 3 & 4 \\
\hline 1.15 & $\begin{array}{l}\text { Gelan dauden haurren familia-ereduak baino ez di- } \\
\text { tut lantzen }\end{array}$ & 1 & 2 & 3 & 4 \\
\hline 1.16 & $\begin{array}{l}\text { Edozein familia motak eskolan irudikatzen den fa- } \\
\text { miliarekin bere burua identifikatzeko aukera du }\end{array}$ & 1 & 2 & 3 & 4 \\
\hline 1.17 & $\begin{array}{l}\text { Material didaktikoa moldatzea zaila da, familia } \\
\text { aniztasunari egokitzeko }\end{array}$ & 1 & 2 & 3 & 4 \\
\hline
\end{tabular}




\section{Adierazi X batekin gelan dauden familia-ereduak:}

\begin{tabular}{|c|}
\hline 2.1. Familia nuklearra (gurasoak eta seme-alabak) \\
\hline 2.2. Guraso bakarreko familia \\
\hline 2.3. Adopziozko familia \\
\hline 2.4. Familia homoparentala (sexu bereko bikotez osatua) \\
\hline $\begin{array}{l}\text { 2.5. Familia berreraikia } \\
\text { (seme-alabaren bat aldez aurretiko harreman batetik dator) }\end{array}$ \\
\hline 2.6. Harrera-familia \\
\hline 2.7. Etorkinen familia \\
\hline 2.8. Banatutako gurasoen familia \\
\hline 2.9. Familia hedatua (gurasoak eta aiton-amonak) \\
\hline 2.10. Ugalketa lagunduaren bidez jaiotako haurren familia \\
\hline 2.11. Subrogazioaren bidez sortutako familia \\
\hline 2.12. Beste batzuk \\
\hline
\end{tabular}

\section{Adierazi eskolan dauden material pedagogikoetan orokorrean agertzen den familia-eredua:}

\begin{tabular}{|l|l|}
\cline { 2 - 2 } \multicolumn{1}{c|}{} & \multicolumn{1}{c|}{ Familia-eredua } \\
\hline 3.1. Ipuin eta testu literarioetan & \\
\hline 3.2. Filmetan & \\
\hline 3.3. Joko eta jostailuetan & \\
\hline 3.4. Antzerkietan & \\
\hline 3.5. Abestietan & \\
\hline 3.6. Marrazki eta argazkietan & \\
\hline
\end{tabular}




\section{Adierazi X batekin:}

\begin{tabular}{|l|l|l|}
\cline { 2 - 3 } \multicolumn{1}{c|}{} & Bai & Ez \\
\hline 4.1. Amaren eguna ospatzen dugu & & \\
\hline 4.2. Aitaren eguna ospatzen dugu & & \\
\hline 4.3. Abenduan neguko oporrak ospatu beharrean, Gabonak ospatzen ditugu & & \\
\hline 4.4. Gelan zuhaitz genealogikoak osatzen ditugu & & \\
\hline 4.5. Gelan jaiotzako fitxa betetzen dugu & & \\
\hline 4.6. Familia aniztasuna lantzeko protokolo edo lanerako gida bat dugu & & \\
\hline
\end{tabular}

\section{Adierazi $X$ batekin familia aniztasuna lantzeko ezagutzen dituzun} materialak:

\begin{tabular}{|l|l|}
\hline & 5.1. Familia Milakolore proiektua (Elkar ed.) \\
\hline & 5.2. Familium XX1 liburua (Canyet eta Bellvehí, 2012) \\
\hline & 5.3. Familia guztien aldeko ipuinak bilduma (A Fortiori ed.) \\
\hline & 5.4. Nuestra Casa liburua (Göbel eta Knorr, 2016) \\
\hline & 5.5. Txinatik etorritako printzesa liburua (Martín eta García, 2004) \\
\hline & 5.6. Paula tiene dos mamás liburua (Newman, 2003) \\
\hline 5.7. Teo lagun baten etxean liburua (Denou, 2007) \\
\hline 5.8. Buscando a Dory filma (Stanton eta MacLane, 2016) \\
\hline 5.9. Beste batzuk___
\end{tabular}

OHARRAK (nahi baduzu, adierazi edozein iradokizun edo iruzkin): 


\section{Cuestionario}

Edad:

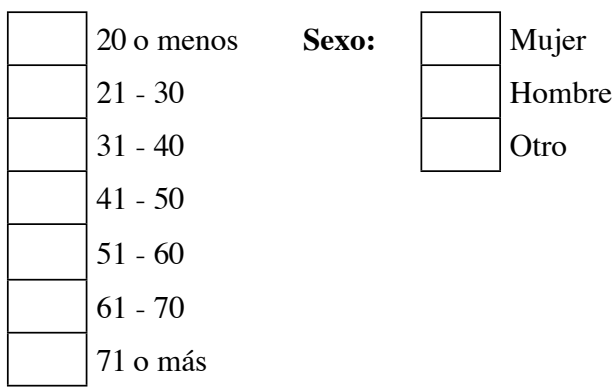

Curso:

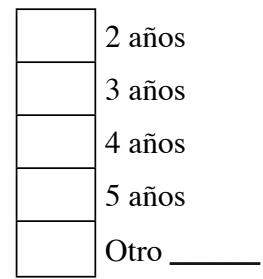

\section{Indique el grado de acuerdo o desacuerdo con las siguientes afirma-} ciones (si quiere añadir algún comentario, dispone de un espacio debajo de cada afirmación):

\begin{tabular}{|c|c|c|c|}
\hline $\mathbf{1}$ & $\mathbf{2}$ & $\mathbf{3}$ & $\mathbf{4}$ \\
Nada de acuerdo & Algo en desacuerdo & Algo de acuerdo & Totalmente de acuerdo \\
\hline
\end{tabular}

\begin{tabular}{|c|c|c|c|c|}
\hline $\begin{array}{l}\text { 1.1. En la universidad, recibí formación sobre la diversi- } \\
\text { dad familiar }\end{array}$ & 1 & 2 & 3 & 4 \\
\hline $\begin{array}{l}\text { 1.2. En el colegio, he recibido formación sobre la diversi- } \\
\text { dad familiar }\end{array}$ & 1 & 2 & 3 & 4 \\
\hline $\begin{array}{l}\text { 1.3. He recibido formación complementaria sobre la di- } \\
\text { versidad familiar fuera del colegio (cursos ) }\end{array}$ & 1 & 2 & 3 & 4 \\
\hline $\begin{array}{l}\text { 1.4. Es necesaria más información sobre la diversidad fa- } \\
\text { miliar }\end{array}$ & 1 & 2 & 3 & 4 \\
\hline $\begin{array}{l}\text { 1.5. Las familias formadas por el padre, la madre y los/as } \\
\text { hijos/as son las mejores para el desarrollo infantil }\end{array}$ & 1 & 2 & 3 & 4 \\
\hline $\begin{array}{l}\text { 1.6. Cuando en la familia solo está la madre, a los/as hi- } \\
\text { jos/as les falta la influencia masculina }\end{array}$ & 1 & 2 & 3 & 4 \\
\hline
\end{tabular}




\begin{tabular}{|c|c|c|c|c|c|}
\hline 1.7. & $\begin{array}{l}\text { No hace falta que las parejas homosexuales sean vi- } \\
\text { sibles en la escuela (p. ej. No es necesario que en } \\
\text { los documentos oficiales de la escuela aparezcan las } \\
\text { dos madres) }\end{array}$ & 1 & 2 & 3 & 4 \\
\hline 1.8. & $\begin{array}{l}\text { Los/as inmigrantes tienen que interiorizar nuestras } \\
\text { costumbres }\end{array}$ & 1 & 2 & 3 & 4 \\
\hline 1.9. & $\begin{array}{l}\text { Los/as niños/as que fueron adoptados tienen más di- } \\
\text { ficultades en la escuela }\end{array}$ & 1 & 2 & 3 & 4 \\
\hline 1.10 & $\begin{array}{l}\text { Los diversos modelos familiares no hay que tratar- } \\
\text { los en un tema particularmente }\end{array}$ & 1 & 2 & 3 & 4 \\
\hline 1.11 . & La diversidad familiar crea dificultades & 1 & 2 & 3 & 4 \\
\hline 1.12 . & $\begin{array}{l}\text { Entre el personal docente los diversos modelos fa- } \\
\text { miliares se tratan con naturalidad }\end{array}$ & 1 & 2 & 3 & 4 \\
\hline 1.13 & Es difícil trabajar la diversidad familiar en clase & 1 & 2 & 3 & 4 \\
\hline 1.14 & $\begin{array}{l}\text { Cuando hablo sobres las familias, hago referencia a } \\
\text { diversos modelos familiares }\end{array}$ & 1 & 2 & 3 & 4 \\
\hline 1.15 & $\begin{array}{l}\text { Solo trabajo los modelos familiares que hay presen- } \\
\text { tes en clase }\end{array}$ & 1 & 2 & 3 & 4 \\
\hline 1.16 . & $\begin{array}{l}\text { Cualquier tipo de familia se puede identificar con la } \\
\text { familia que se representa en la escuela }\end{array}$ & 1 & 2 & 3 & 4 \\
\hline 1.17 & $\begin{array}{l}\text { Es difícil modificar el material didáctico para que se } \\
\text { adapte a la diversidad familiar }\end{array}$ & 1 & 2 & 3 & 4 \\
\hline
\end{tabular}


2. Indique con una $X$ los modelos familiares que hay en clase:

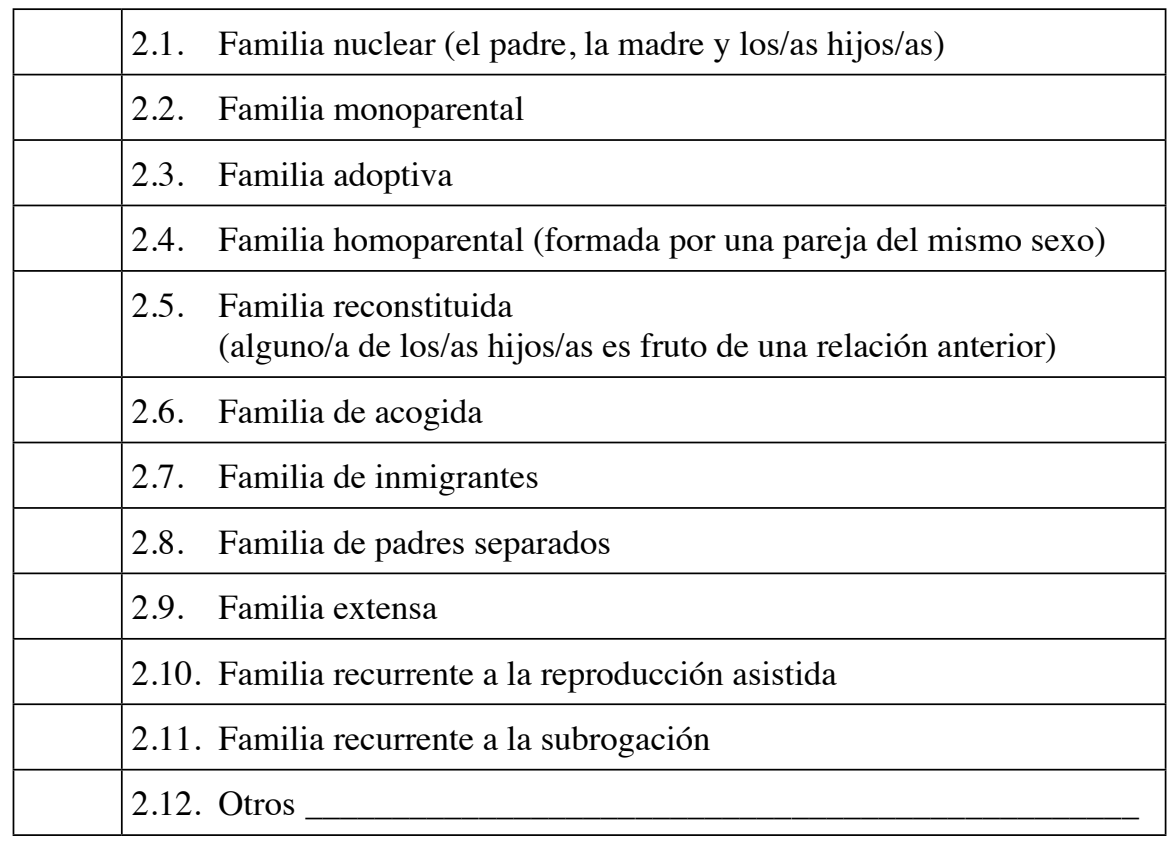

\section{Indique el modelo familiar que aparece normalmente en el material pedagógico que hay en la escuela:}

\begin{tabular}{|l|l|}
\cline { 2 - 2 } \multicolumn{1}{c|}{} & \multicolumn{1}{c|}{ Modelo familiar } \\
\hline 3.1. Cuentos y textos literarios & \\
\hline 3.2. Películas & \\
\hline 3.3. Juegos y juguetes & \\
\hline 3.4. Teatros & \\
\hline 3.5. Canciones & \\
\hline 3.6. Dibujos y fotografías & \\
\hline
\end{tabular}




\section{Indique con una $X$ :}

\begin{tabular}{|l|l|l|}
\cline { 2 - 3 } \multicolumn{1}{l|}{} & Si & No \\
\hline 4.1. Celebramos el día de la madre & & \\
\hline $\begin{array}{l}\text { 4.3. En diciembre, en vez de celebrar las vacaciones de invierno, cele- } \\
\text { bramos la navidad }\end{array}$ & & \\
\hline $\begin{array}{l}\text { 4.4. En clase hacemos árboles genealógicos } \\
\text { 4.5. En clase rellenamos la ficha de nacimiento }\end{array}$ & & \\
\hline $\begin{array}{l}\text { 4.6. Tenemos un protocolo o guía de trabajo para trabajar la diversidad } \\
\text { familiar }\end{array}$ & & \\
\hline
\end{tabular}

5. Indique con una $X$ los materiales que conoce para trabajar la diversidad familiar:

\begin{tabular}{|l|l|}
\hline & 5.1. Proyecto Familia Milakolore (Ed. Elkar) \\
\hline & 5.2. Libro Familium XX1 (Canyet y Bellvehí, 2012) \\
\hline & 5.3. Colección Cuentos en favor de todas las familias (Ed. A Fortiori) \\
\hline & 5.4. Libro Nuestra Casa (Göbel y Knorr, 2016) \\
\hline & 5.5. Libro La Princesa que vino de China (Martín yGarcía, 2004) \\
\hline & 5.6. Libro Paula tiene dos mamás (Newman, 2003) \\
\hline & 5.7. Libro Teo va a casa de una amiga (Denou, 2003) \\
\hline & 5.8. Película Buscando a Dory (Stanton y MacLane, 2016) \\
\hline & 5.9. Otros _ \\
\hline
\end{tabular}

COMENTARIOS (indique cualquier sugerencia o comentario que desee): 